\title{
PAST EARTHQUAKE TIMING AND MAGNITUDE ALONG THE INGLEWOOD FAULT, TARANAKI, NEW ZEALAND
}

\author{
A. G. Hull'
}

\begin{abstract}
Several active normal faults in the onshore and offshore regions of Taranaki are capable of generating large earthquakes and associated strong ground shaking. Historical earthquakes are concentrated offshore of Cape Egmont, and no significant earthquakes have been detected along the major onshore surface faults. The northeaststriking Inglewood fault is a major onshore, southward-dipping normal fault. It has a known length of c. $20 \mathrm{~km}$ and an average scarp height of c. $3 \mathrm{~m}$ on landforms less than about 15,000 yrs old. Three subsurface excavations at two sites along the Inglewood fault about $15 \mathrm{~km}$ from New Plymouth have revealed three surface fault displacements during the last c. 13,000 years. Earthquakes resulting in about $1.2 \mathrm{~m}$ of surface displacement occurred at c. 3,500 radiocarbon yrs BP; between 4,000 and 9,000 radiocarbon yrs BP; and between 10,000 and 13,000 radiocarbon yrs BP, judged by the amount of vertical offset of dated volcanic ash layers. Based on average single-event fault slip values of $1.2-3.0 \mathrm{~m}$ and a fault length of $20-30 \mathrm{~km}$, the estimated earthquake magnitudes associated with these past movements range from $M_{w} 6.7$ to 7.2 .
\end{abstract}

\section{INTRODUCTION}

One of the greatest uncertainties in understanding the long-term seismic hazard in Taranaki is the timing and magnitude of large earthquakes associated with past activity of geologic faults. Active surface faults are of greatest importance because they indicate brittle failure of rocks in association with earthquakes in the recent geological past. Only moderate to large earthquakes $(M>\sim 6.5)$ are associated with ground surface rupture in New Zealand. Thus, if the timing and amount of ground displacement in past surface ruptures along active faults can be determined for the last several thousand years in Taranaki, then the magnitudes and frequency of past large earthquakes can be estimated also. These data are useful for assessing the long-term earthquake risk for a part of New Zealand where considerable investment in petrochemical extraction and manufacturing has been made over the last two decades.

The primary focus of this study is to determine the timing and magnitude of past large earthquakes along the Inglewood fault, located about $15 \mathrm{~km}$ south of New Plymouth (Figure 1). The Inglewood fault is the nearest known active fault to many of the major petrochemical developments in Taranaki, and was investigated by excavations across the fault scarp at two localities, one at either end of its known surface trace. This paper reports the results of these investigations by first describing the geological and seismological setting of the Taranaki region, then presenting the results of the trenching

1 Institute of Geological and Nuclear Sciences, Lower Hutt (Member) investigations along the Inglewood fault with respect to the amounts of surface fault displacement, the timing of past earthquakes and estimation of their magnitudes.

\section{GEOLOGICAL SETTING OF TARANAKI}

The Taranaki region lies to the west of the active boundary zone where relative motions of the Pacific and Australian plates over the last 30 million years have been accommodated by various mechanisms including fault movements and earthquakes (Inset, Figure 1). Unlike the main plate boundary zone, the Taranaki region has been affected by only minor deformations associated with the development of the plate boundary. Nevertheless, a complex geological history involving several phases of fault movement and periods of subsidence and uplift over the last 80 million years is recorded in the rocks underlying Taranaki [8].

The most recent phase of tectonic movement began about two million years ago, and has resulted in the reactivation of faults formed in earlier periods. This renewed fault activity has been accompanied by regional southwest tilting to accommodate the continued gradual stretching and extension of the crust underlying the Taranaki and Wanganui offshore areas.

The Cape Egmont fault zone (Figure 1)-with a known length of more than $200 \mathrm{~km} \mathrm{[12]-is} \mathrm{the} \mathrm{main} \mathrm{geological} \mathrm{structure} \mathrm{of}$ western Taranaki. It lies offshore and separates the stable Western Platform from the Taranaki Graben. The Cape Egmont fault is the major structural element within the fault zone, and consists of four geomorphologically distinct segments of $\mathrm{N}$ - and NE-striking normal faults that are generally downthrown to the east [12]. The presence of a scarp offsetting sea-floor deposits 


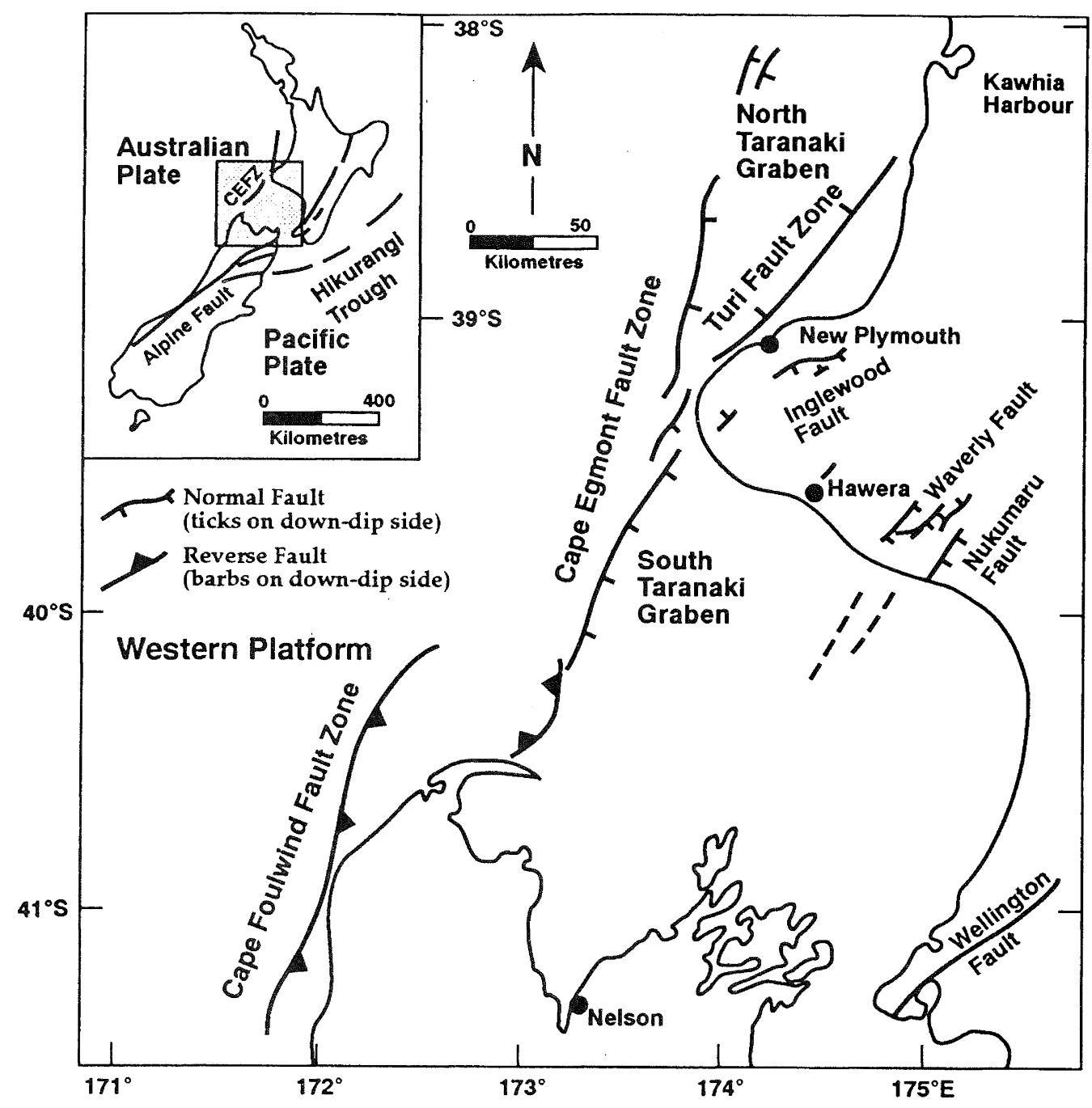

Figure 1: Structural geological setting of the Taranaki-Wanganui-Northwest Nelson regions of central New Zealand. Inset shows plate tectonic setting of the New Zealand region.

$<14,000$ years old suggests geologically recent earthquake and faulting activity along much of the fault offshore of the Taranaki Peninsula. Average vertical fault separation rates range from 0.2 to $0.6 \mathrm{~mm} / \mathrm{yr}$ over the last 14,000 years for the segment closest to the Maui Platform, while the least well-expressed segment closest to the Taranaki Peninsula has an average vertical separation rate of about $0.3 \mathrm{~mm} / \mathrm{yr}$ for the same time interval.

Time planes useful for dating landforms are provided by airfall volcanic ash layers (tephra) and volcanoclastic debris flows (lahars), that have accumulated around Mt. Taranaki for at least the last 100,000 years. During this time, the mountain has been built up by successive eruptions of lava and volcanic ash, and on at least two occasions in the last 25,000 years, large parts of the former mountain (more than $10 \mathrm{~km}^{3}$ ) have collapsed catastrophically to form widespread debris flow mounds and associated deposits [11]. The present Mt. Taranaki is probably not much older than about 10,000 years; most of the upper part of the mountain has been built in the last 3,000 years [11].

All the larger eruptions of Taranaki volcano have been accompanied by widespread tephra fall in Taranaki. The regions surrounding Mt. Taranaki, particularly in the north, east and southeast-the major downwind directions-have accumulated great thicknesses of tephra. Laharic debris is abundant in regions surrounding Mt Taranaki. The ages of many of the volcanic ash layers and debris flows have been determined by radiocarbon dating of enclosed organic layers $[11,1]$. Where these dated volcanic ash layers have been displaced by past fault movements, they have been used in this study to infer the timing of past earthquakes.

\section{SEISMICITY OF TARANAKI}

Earthquake epicentres recorded in the New Zealand National Earthquake Information Database and by Latter [9] as part of volcanological research indicate the pattern of historical seismicity for Taranaki (Figure 2). The earliest earthquake in the database is reported as having occurred in 1815 , but where and when it took place is doubtful [4]. Other earthquakes that have been felt strongly in the Taranaki region include:

- 1 January 1853 ; estimated magnitude 6.8 , intensity about MM VIII in New Plymouth. This intensity of shaking is the highest known from western Taranaki during historic times [5]. Epicentre located at $39^{\circ} \mathrm{S}, 174^{\circ} \mathrm{E}$ [14]. 


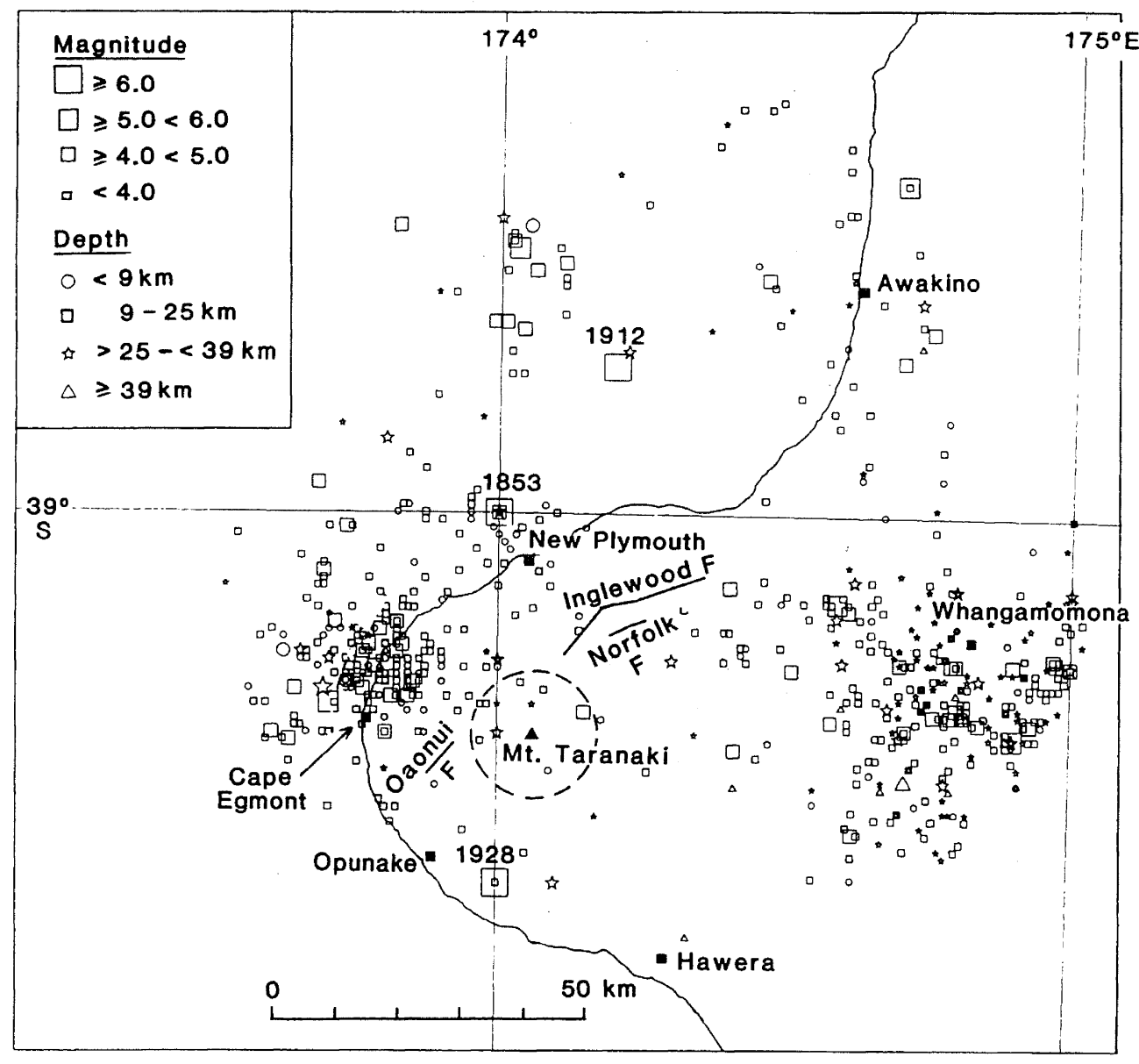

\section{Figure 2: Earthquake epicentres from the New Zealand National Earthquake Information Database and studies by Latter [9] for the Taranaki region. Surface traces of known active faults from onshore Taranaki are indicated.} VIII "in parts of Taranaki" [4]

- $\quad 26$ May 1912; magnitude about 6; intensity about MM VII in New Plymouth $30-40 \mathrm{~km}$ southwest of the assigned epicentre (Figure 2)

- 7 March 1928; magnitude about 6.0, intensity at New Plymouth about MM VII.

- 5 November 1974; magnitude 6.1 Opunake earthquake MM V intensity in New Plymouth, MM VI in south Taranaki [13].

From the distribution of earthquake epicentres, two major concentrations can be recognised (Figure 2): one in western/northwestern Taranaki, and the other well to the east, approximately in the Whangamomona area.

Most earthquakes in Taranaki area have occurred to the west and northwest of Mt. Taranaki. These earthquakes appear to cluster in the region immediately north of Cape Egmont where the Cape Egmont fault zone changes to a more northerly strike and becomes a discontinuous zone of overlapping, short faults. Earthquake hypocentres are generally at depths less than about $25 \mathrm{~km}$. Few earthquakes have been located in the vicinity of the known active faults near Inglewood and Opunake.
Since about 1973 earthquake analysis by Latter [9] has concentrated on earthquakes that appeared to originate within about $30 \mathrm{~km}$ of Mt Taranaki, especially those within the volcanic structure itself. Most earthquakes of magnitude more than about 2.5 on the Inglewood fault would probably have been detected if any had occurred, but only about three earthquakes-all of $\mathrm{M}<4.5$--have been detected within $10 \mathrm{~km}$ of the Inglewood and Norfolk faults since 1973 (Figure 2, 3). Seismicity of the area surrounding the Inglewood fault can, therefore, be described as low at present.

\section{INGLEWOOD FAULT}

The surface trace of the Inglewood fault extends c. $20 \mathrm{~km}$ from Kaimiro in the southwest to the Waitara River in the northeast (Figure 3). The fault has a general northeast $\left(030^{\circ}\right)$ strike, except along a $4 \mathrm{~km}$ section through the town of Inglewood, where it strikes east-west. The fault dips generally southward, with a predominantly normal sense of displacement. An increase in scarp height to the northeast of Mt Taranaki corresponds with an increase in the age of surficial deposits, and demonstrates continued fault movement over at least the last 60,000 years. Studies reported by Hull and Matsuda [7] suggested that the last surface displacement along the southwestern part of the Inglewood fault occurred more than $1345 \pm 50$ radiocarbon yrs $\mathrm{BP}$, but no systematic study of the timing and magnitude of past earthquakes has previously been undertaken. 


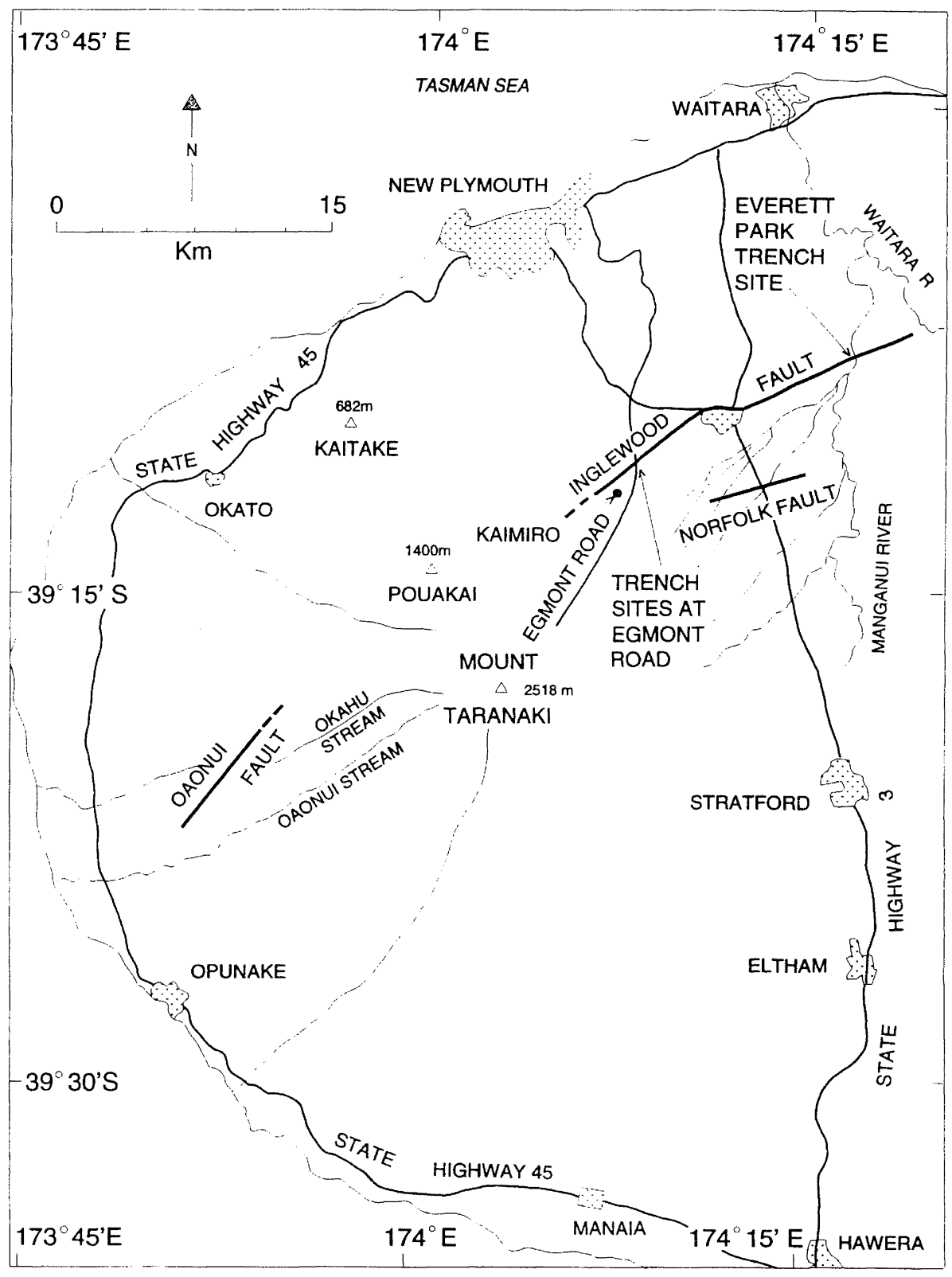

Figure 3: Location of trench sites along the Inglewood fault reported in this paper.

\section{PALEOSEISMICITY OF THE INGLEWOOD FAULT}

Three trenches were excavated across the Inglewood fault: one at the northeastern end at Everett Park; and two near the southwestern end at Egmont Road (Figure 3). The purpose of the trenches was to determine the age and the amount of offset of geological layers that had been displaced by past fault movements. Detailed studies of the composition and age of volcanic ash layers (tephra formations; Table 1) by Neall [10, 11], Alloway [1] and Alloway and others [2] provide the chronology used in this study to determine the number and age of past fault movements along the Inglewood fault (Table 1).

The age of faulting from earthquake 1 (Table 2) is well constrained by vertical offsets of several tephra formations preserved at a trench at Egmont Road (Figure 4). Inglewood Tephra Formation (c. 3,600 yrs BP) is clearly offset by movement along the Inglewood fault, while Manganui Tephra Formation (c. 3,300 yrs BP) is clearly undisplaced by any past fault movement. Although there is no Manganui Tephra preserved at Everett Park, a clear vertical displacement of Inglewood Tephra is preserved there (Figure 5). These observations indicate an age of c. 3,500 yrs BP for the last surface fault displacement along the surface trace of the Inglewood fault.

Faulting during earthquake 2 is the least well constrained of the inferred past earthquakes along the Inglewood fault. Korito Tephra Formation (c. 4,000 yrs BP) is displaced at Egmont Road by the same amount as the overlying Inglewood Tephra. Earthquake 2, therefore, occurred after c. 4,000 yrs BP. Kaponga Tephra (c. 9,000 yrs BP) is displaced by a greater amount than Inglewood and Korito tephra; thus earthquake 2 must have occurred at some time between c. 4,000 yrs BP and c. 9,000 yrs BP. At Everett Park, where the number and thicknesses of tephra layers are less than at Egmont Road, only a zone of fissuring away from the fault marks earthquake 2 . Without distinct, dated tephra layers preserved in the interval 


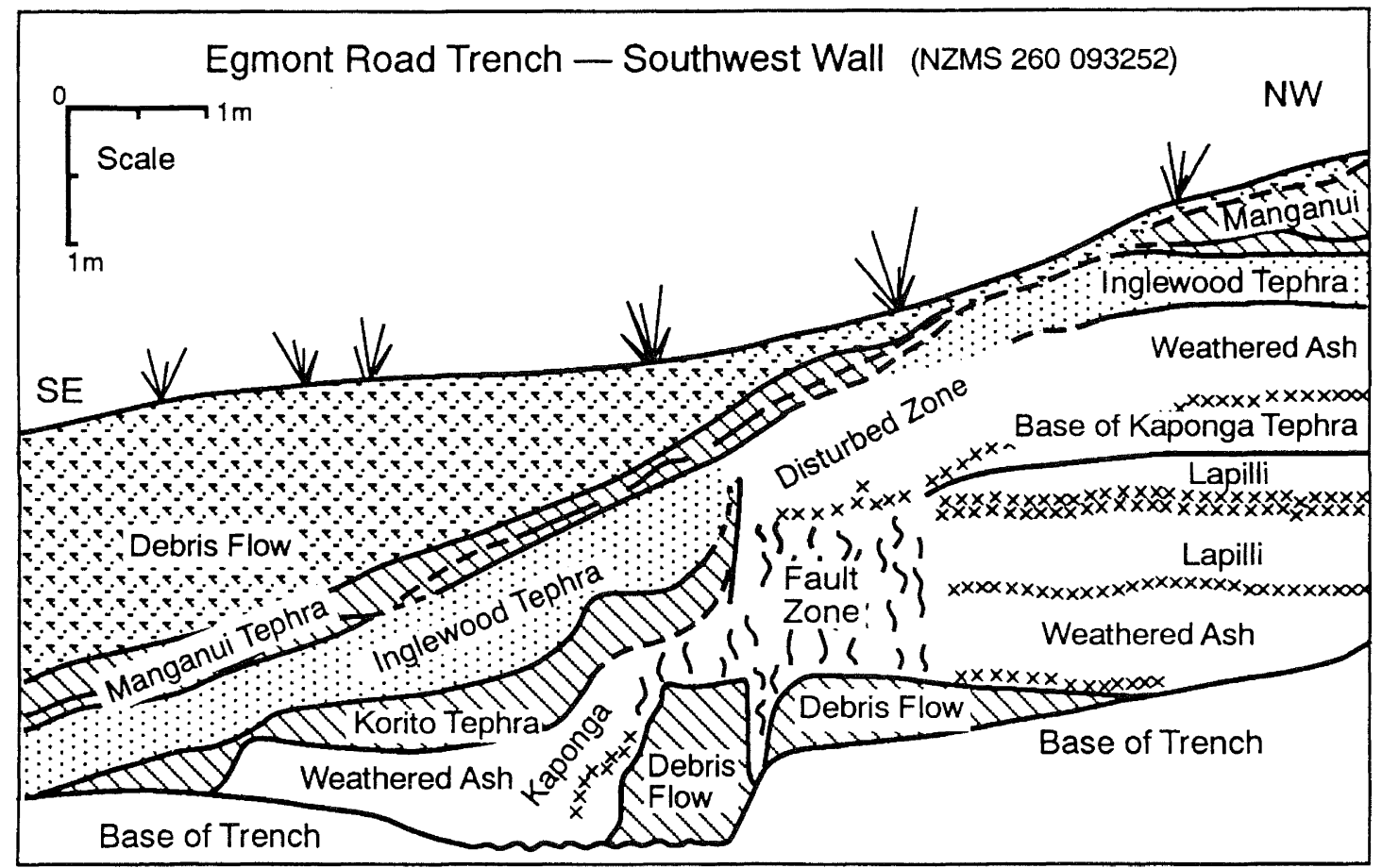

Figure 4: Log of trench wall showing the vertical separation of tephra and lahar layers at Egmont Road\#2 site, southwest end of the Inglewood fault.

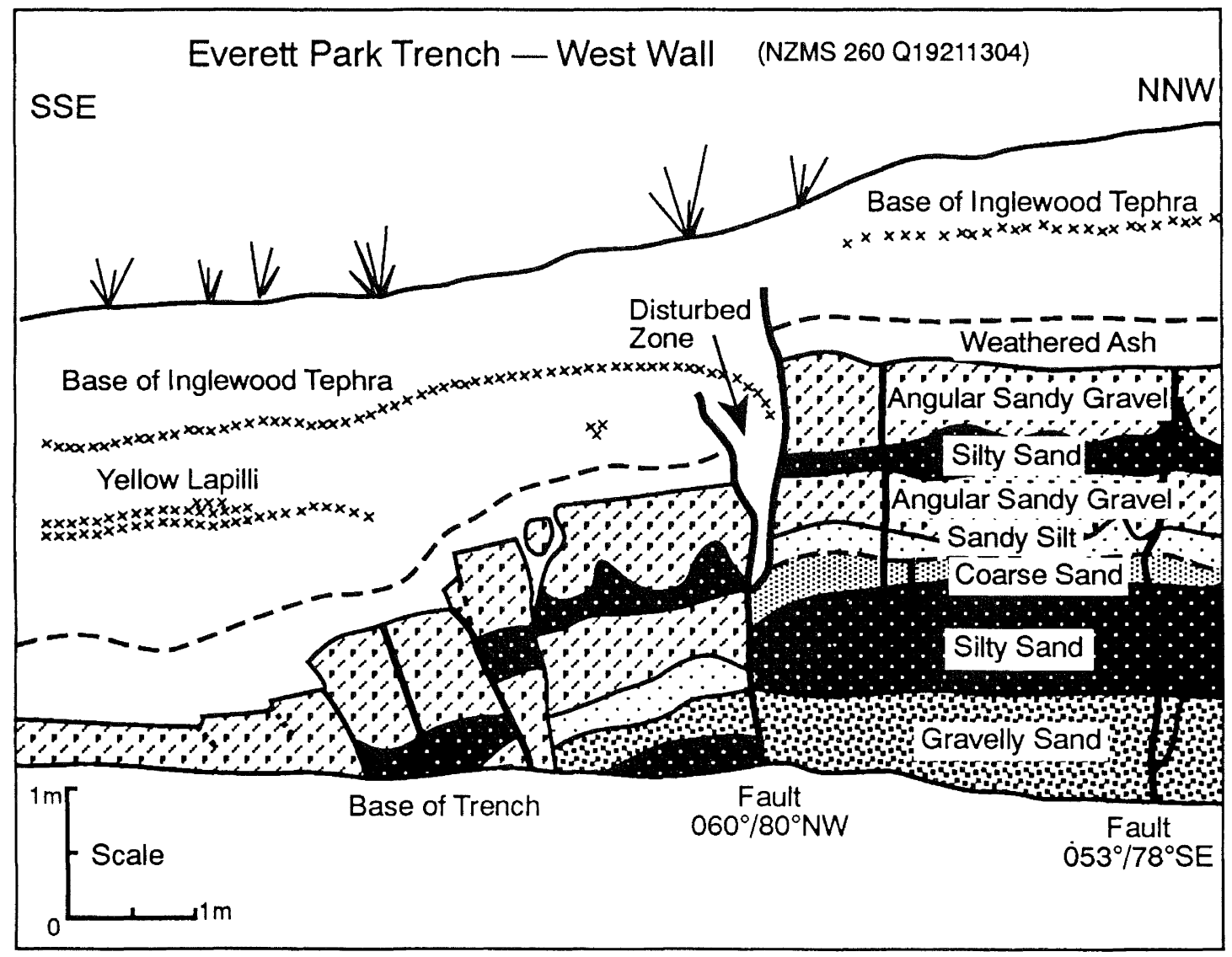

Figure 5: Log of trench wall showing the vertical separation of tephra and lahar layers at Everett Park site, northeast end of Inglewood fault. 
Table 1: Dated tephra formations and their displacement by past surface fault movements at trench sites along the Inglewood fault.

Tephra Formation
Formation age (radiocarbon yrs BP)
Earthquakes displacing tephra

\begin{tabular}{lll}
\hline Manganui & $3320 \pm 60$ & Undisplaced \\
Inglewood & $3610 \pm 80$ & Earthquake 1 \\
Korito & $3870 \pm 110$ & Earthquake 1 \\
Kaponga & $8947 \pm 130$ & Earthquakes 1, 2 \\
& & \\
Konini & $10150 \pm 100$ & Earthquakes 1, 2 \\
Kaihouri & $12900 \pm 200$ & Earthquakes 1, 2, 3 \\
\hline
\end{tabular}

Notes: $\quad$ Tephra Formations and ages after [2]

Table 2: Vertical separation at the ground surface associated with past movements along the Inglewood fault.

\begin{tabular}{cccc}
$\begin{array}{c}\text { Earthquake } \\
\text { (radiocarbon yrs BP) }\end{array}$ & $\begin{array}{c}\text { Everett Park } \\
(\mathbf{m})\end{array}$ & $\begin{array}{c}\text { Egmont Rd\# } \\
(\mathbf{m})\end{array}$ & $\begin{array}{c}\text { Egmont Rd \#2 } \\
(\mathbf{m})\end{array}$ \\
\hline $\begin{array}{l}\text { Earthquake 1 } \\
(\mathrm{c} .3,500)\end{array}$ & $>0.4<1.2$ & 0.8 & 1.2 \\
$\begin{array}{c}\text { Earthquake 2 } \\
(>4,000<9,000)\end{array}$ & $\begin{array}{c}\text { Fissures \& } \\
\text { minor displacements }\end{array}$ & 1.0 & 1.2 \\
$\begin{array}{c}\text { Earthquake 3 } \\
(>10,000<13,000)\end{array}$ & $>0.8<1.6$ & 0.7 & $<2.6$
\end{tabular}

between c. 9,000 yrs BP and c. 4,000 yrs BP at the trench sites, the timing of earthquake 2 cannot be resolved more accurately.

The timing of faulting during earthquake 3 is constrained at both Everett Park (Figure 5) and Egmont Road by a greater offset of Kaihouri Tephra and the underlying lahar deposits (estimated age of c. 13,000 yrs BP; [1]) than for Konini Tephra (c. 10,000 yrs BP). These data indicate that earthquake 3 caused surface faulting along the Inglewood fault at some time between $\mathrm{c}$. 10,000 yrs BP and c. 13,000 yrs BP.

Trenching results indicate that three surface fault displacements have occurred along the Inglewood fault in the last 13,000 radiocarbon years. The possible recurrence interval between earthquake 1 and 2 is 230-6990 radiocarbon yrs, and between earthquake 2 and 3; 973-9,340 radiocarbon yrs. These wide ranges in possible recurrence interval result from poor constraint on the timing of earthquake 2. However, at least 3,260 radiocarbon years has elapsed since the last fault displacement, and about 4,000 years-the average midpoint of the two recurrence interval ranges-seems a reasonable estimate of the average recurrence interval for the Inglewood fault with the data presently available.

\section{EARTHQUAKE MAGNITUDE}

In the absence of surface rupture along the Inglewood fault during historic times, when instrumental measurements of earthquake magnitude could be made, the magnitude of past earthquakes can be estimated only from measurements of the fault length and amount of fault displacement. Two main methods are available for making these estimates from surface faulting along the Inglewood fault:

(1) Estimates of earthquake magnitude from fault data using the formulae of Bonilla and others [3]. These empirical formulae were derived by using an ordinary least-squares-regression analysis on records of surface wave magnitudes $\left(\mathrm{M}_{\mathrm{s}}\right)$ for 58 historical earthquakes from throughout the world with their reported surface rupture lengths and surface displacements. In the Bonilla and others [3] empirical relations, only a few data points were from normal faults, and none of these faults are in New Zealand. They found only a moderate correlation between magnitude and rupture length, and calculated magnitudes have a standard deviation of \pm 0.3 units of surface-wave magnitude;

(2) Calculation of the moment magnitude $\left(\mathbf{M}_{w}\right)$ of earthquakes generated by the fault using estimates of the fault area, crustal rock rigidity and mean slip values for individual fault displacements. When good quality fault slip data are available, as in this study, then moment magnitude provides the better method for estimating past earthquake magnitude because it is based on data from the specific fault producing the earthquake hazard.

In this study the amount of surface displacement occurring during each of the past three earthquakes has been determined from the trench exposures along the Inglewood fault (Table 2). These measurements show the vertical separation of dated tephra layers, and only represent the vertical component of movement at each trench site. Horizontal offsets of topography and sub-horizontal lineations on the fault plane, that usually indicate a significant component of horizontal slip, are absent along the 
Table 3 Range of calculated earthquake magnitudes generated by past movements along the Inglewood fault.

\begin{tabular}{lcccc}
$\begin{array}{l}\text { Length } \\
(\mathbf{k m})\end{array}$ & $\begin{array}{c}\text { Depth } \\
(\mathbf{k m})\end{array}$ & $\begin{array}{c}\text { Mean Slip } \\
\mathbf{( m )}\end{array}$ & $\begin{array}{c}\mathbf{M}_{\mathbf{o}}{ }^{\mathbf{b}} \\
\left(\mathbf{N m} \mathbf{x 1 0}{ }^{19}\right)\end{array}$ & $\mathbf{M}_{\mathbf{w}}{ }^{\mathrm{C}}$ \\
\hline 20 & 15 & 1.2 & 1.247 & 6.7 \\
30 & 25 & 3.0 & 7.794 & 7.2 \\
30 & 20 & 2.0 & 4.157 & $7.1^{*}$ \\
\hline
\end{tabular}

Notes:

a Mean slip estimated for total fault plane with $60^{\circ}$ dip

b $M_{0}=$ seismic moment assuming a rigidity of $3 \times 10^{10} \mathrm{Nm}^{-2}$

c $\mathrm{M}_{\mathrm{W}}=$ Moment magnitude calculated from the equation: $M_{\mathrm{W}}=2 / 3\left(\log _{10} \mathrm{M}_{0}-9.05\right)$. After [6]

* Preferred value

Inglewood fault. I assume, therefore, that the fault is normal (ie. only dip-slip displacement), dips $60^{\circ}$ south, and the measured vertical separations represent the total slip on the fault during each earthquake at that site.

The fault displacement data support an interpretation that all three earthquakes caused surface displacement along the entire $20 \mathrm{~km}$ of presently preserved surface trace, and that an average surface displacement of about $1.2 \mathrm{~m}$ resulted during each event A maximum value for vertical separation is less than $2 \mathrm{~m}$, judged by the uniformity of scarp height along sections of the fault trace where the same aged surface has been displaced

Earthquake moment magnitudes can be calculated using several estimates of fault parameters (Table 3). Using vertical displacement values measured in the trenches, the total known fault length of $20 \mathrm{~km}$ and an assumed shallow focal depth of 15 $\mathrm{km}$, a magnitude of $\mathrm{M}_{\mathrm{w}} 6.7$ is estimated for past earthquakes causing surface displacement along the Inglewood fault (Table 3). This is a minimum estimate of past earthquake magnitude because it assumes a shallow seismic source, and that the observed fault length represents the total length of subsurface rupture.

Studies of surface faulting and associated seismicity indicate that faulting at depth generally extends beyond the observed surface break, and $150 \%$ of the known fault length is a reasonable maximum estimate of the total length of subsurface fault rupture. In this case, it is assumed that the earthquake is generated near the base of the crust at $25 \mathrm{~km}$ depth, and because of this depth, about three times the slip observed at the ground surface may be required to produce the observed $1.2 \mathrm{~m}$ of vertical displacement at the ground surface. Calculations from these data result in a maximum estimated earthquake magnitude of $\mathbf{M}_{\mathrm{w}} 7.2$ (Table 3).

Consideration of the present depth distribution of crustal seismicity in Taranaki suggests a focal depth of about $20 \mathrm{~km}$ and an average slip of $2 \mathrm{~m}$ over $30 \mathrm{~km}$ of fault plane as reasonable estimates of earthquake fault parameters. These estimates indicate an earthquake of $M_{w} 7.1$, and accordingly I adopt this value for the typical earthquake magnitude associated with past earthquakes along the Inglewood fault (Table 3). This result for the Inglewood fault also lies within the range of surface wave earthquake magnitudes calculated using the method of Bonilla and others [4].

\section{NORFOLK FAULT}

The NE-striking Norfolk fault is upthrown to the southeast and has a total length of $5 \mathrm{~km}$ (Figure 3). The fault trace was not trenched for this study. However, the close association of the Norfolk and Inglewood faults and their similar scarp heights suggests that they could be linked at depth. In this study the Norfolk fault is assumed to be part of the Inglewood fault zone, and is not regarded as a separate seismic source or significant additional component to the inferred magnitude associated with movement along the Inglewood fault. Trenching across the Norfolk fault to determine the number and amount of past surface displacements along the fault would be necessary to confirm this assumption.

\section{CONCLUSION}

Three trenches at two sites along the Inglewood fault reveal three past surface fault displacements of about $1.2 \mathrm{~m}$ at c. 3,500 yrs BP; at some time between 4,000 and 9,000 yrs BP; and at some time between 10,000 and $13,000 \mathrm{yrs}$ BP. Based on average fault dip-slip values of 1.2 to $3.0 \mathrm{~m}$ and a fault rupture length of 20 to $30 \mathrm{~km}$, estimated earthquake magnitudes associated with these past movements range from $M_{w} 6.7$ to 7.2 . A value of $M_{w} 7.1$ is preferred for earthquakes associated with past surface fault displacements along the Inglewood fault.

\section{ACKNOWLEDGMENTS}

This study was funded jointly by Fletcher Challenge Methanol, the Taranaki Regional Council and the Foundation for Research, Science and Technology. Cheerful field assistance by Russ Van Dissen and Grant Dellow helped with the description and interpretation of stratigraphy exposed in the trenches in often adverse weather conditions. Reviews by Russ Van Dissen and John Latter have improved the text. Institute of Geological and Nuclear Sciences contribution number 229. 


\section{REFERENCES}

1. Alloway, B. V. 1989. The late Quaternary coverbed stratigraphy and tephrochronology of northeastern and central Taranaki. Unpublished Ph.D thesis, Dept. of Soil Science, Massey University, Palmerston North.

2. Alloway, B. V., Stewart, R. B., Neall, V. E., Vucetich, C. G. 1992. Climate of the last Glaciation in New Zealand, based on aerosolic quartz influx in an andesitic terrain. Quaternary Research 38:170-179.

3. Bonilla, M. G., Mark, R. K., Lienkamper, J. J. 1984. Statistical relations among earthquake magnitude, surface rupture length, and surface fault displacement. Bulletin of the Seismological Society of America 74:2379-2411.

4. Eiby, G. A. 1968. An annotated list of New Zealand earthquakes, 1460-1965. New Zealand Journal of Geology and Geophysics 11:630-647.

5. Eiby, G. 1973. A descriptive catalogue of New Zealand earthquakes. Part 2 - Shocks felt from 1846 to 1854. New Zealand Journal of Geology and Geophysics 16:857-907.

6. Hanks, T. C., Kanamori, H. 1979. A moment magnitude scale. Journal of Geophysical Research 84:2348-2350.

7. Hull, A. G., Matsuda, T. 1981. Late Quaternary faulting near Inglewood, North Island, New Zealand (Abstract). Geological Society of New Zealand, Hamilton Conference, Programme and Abstracts: p. 52.

8. King, P. R., Thrasher, G. P. 1992. Post-Eocene development of the Taranaki Basin, New Zealand. American Association of Petroleum Geologists Memoir 53:93-118.
9. Latter, J. H. 1991. Seismicity and surveillance at New Zealand volcanoes. Programme and Abstracts Joint Annual Conference of Geological Society of New Zealand \& New Zealand Soil Science Society. Geological Society of New Zealand miscellaneous publication 59A: p. 82.

10. Neall, V. E. 1972. Tephrochronology and tephrostratigraphy of western Taranaki (N108-109), New Zealand. New Zealand Journal of Geology and Geophysics 15:507-557.

11. Neall, V. E. 1979. Sheets P19, P20, and P21 New Plymouth, Egmont and Mnnnin. "Geological map of New Zealand 1:50,000"1st Edition. DSIR, Wellington.

12. Nodder, S. D. 1993. Neotectonics of the offshore Cape Egmont fault zone, Taranakl Basin, New Zealand. New Zealand Journal of Geology and Geophysics 36:167-184.

13. Robinson, R., Calhaem, I. M., Thomson, A. A. 1976. The Opunake, New Zealand, earthquake of 5 November 1974. New Zealand Journal of Geology and Geophysics 19:335-345

14. Smith, W. D., Berryman, K. R. 1986. Earthquake hazard in New Zealand; inferences from seismology and geology. In: Reilly, W. I.; Harford, B. E. (eds). Recent Crustal Movements of the Pacific Region. Royal Society of New Zealand bulletin 24:223-243. 